Scientia Marina 71(2)

June 2007, 373-382, Barcelona (Spain)

ISSN: 0214-8358

\title{
Bioaccumulation and biochemical responses in mussels exposed to the water-accommodated fraction of the Prestige fuel oil
}

\author{
MONTSERRAT SOLÉ ${ }^{1}$, ASTRID BUET $^{1}$, LAURA ORTIZ $^{2}$, FRANCESC MAYNOU ${ }^{1}$, \\ JOSEP MARIA BAYONA ${ }^{2}$ and JOAN ALBAIGÉS ${ }^{2}$ \\ ${ }^{1}$ Institut de Ciències del Mar (ICM-CSIC), Pg. Marítim de la Barceloneta 37-49, 08003 Barcelona, Spain. \\ E-mail: msole@icm.csic.es \\ ${ }^{2}$ Environmental Chemistry Department (IIQAB-CSIC), Jordi Girona, 18-26,08034 Barcelona, Spain.
}

SUMMARY: The activity of the antioxidant defences catalase (CAT, EC 1.11.1.6), glutathione peroxidase (t-GPX, EC 1.11.1.9), glutathione reductase (GR, EC 1.6.4.2), phase II glutathione $S$-transferase (GST, EC 2.5.1.18) along with the NADPH-dependent cytochrome c (CYP) reductase (EC 1.6.2.4), NADH-dependent cytochrome c reductase (EC 1.6.2.2), and NADH-dependent ferricyanide $\left(\mathrm{b}_{5}\right)$ reductase (EC 1.18.1.1) was determined in the digestive gland of mussels Mytilus galloprovincialis fed with Tetraselmis sp. pre-exposed to the water accommodated fraction of the Prestige oil. Mussel gills were also used for measuring acetylcholinesterase activity (AChE, EC 3.1.1.7) and lipid peroxidation (LP) as an indication of neurotoxicity and oxidative stress damage respectively. Bioaccumulation of the selected polycyclic aromatic hydrocarbons (2 to 6 rings PAHs) in mussels after 2, 4, 7 and 10 days of exposure did not show any significant trend; the 2-3 ring PAHs were best represented $(51 \%)$. A significant $(\mathrm{p}<0.05)$ bioaccumulation in exposed mussels was only observed for some alkylated 2-3 ring PAHs. Biochemical antioxidant responses (CAT, t-GPX and GR) significantly increased over time, regardless of exposure, whereas NADH-dependent reductases and LP were affected, regardless of the length of exposure. However, due to the low solubility of the Prestige crude, the PAH levels reached in exposed mussels were not sufficient to cause a clearly associated biochemical response.

Keywords: Prestige oil spill, Mytilus galloprovincialis, Tetraselmis sp., water-accommodated fraction, biomarkers.

RESUMEN: BIOACUMULACIÓN Y RESPUESTAS BIOQUÍMICAS EN MEJILLONES EXPUESTOS A LA FRACCIÓN ACOMODADA EN AGUA DEL CRUDO DEL PRESTIGE. - La actividad enzimática de las defensas antioxidantes: catalasa (CAT, EC 1.11.1.6), glutatión peroxidasa (t-GPX, EC 1.11.1.9), glutatión reductasa (GR, EC 1.6.4.2), el enzima de fase II glutatión $S$-transferasa (GST, EC 2.5.1.18) y la actividad citocromo c reductasa NADPH-dependiente (CYP) (EC 1.6.2.4), NADH-dependiente (EC 1.6.2.2) y la ferricianida reductasa $\mathrm{NADH}$-dependiente $\left(\mathrm{b}_{5}\right)(\mathrm{EC}$ 1.18.1.1) se determinaron en la glándula digestiva de mejillón Mytilus galloprovincialis alimentado con algas (Tetraselmis sp.) pre-expuestas a la fracción acomodada del agua de crudo del Prestige. En branquias de mejillón se midió la actividad acetilcolinesterasa (AChE, EC 3.1.1.7) como indicador de neurotoxicidad y la peroxidacion lipídica (LP) como indicador de daño por estrés oxidativo. La bioacumulación en mejillones de determinados hidrocarburos aromáticos policíclicos (PAHs de 2 a 6 anillos) después de 2, 4, 7 y 10 días de exposición, no mostró ninguna tendencia significativa, siendo los PAHs de 2-3 anillos los mejor representados (51\%). En los mejillones expuestos sólo se observó una bioacumulación significativa $(\mathrm{p}<0.05)$ en PAHs alquilados de $2-3$ anillos. Las respuestas antioxidantes (CAT, t-GPX y GR) incrementaron de manera significativa con el tiempo, independientemente de la exposición, mientras que las reductasas NADH-dependientes y la LP se vieron afectadas por la exposición pero no por el tiempo de exposición. Sin embargo, debido a la baja solubilidad del crudo del Prestige, los niveles de PAHs alcanzados en los mejillones expuestos, no fueron lo suficientemente altos como para originar una respuesta bioquímica asociada clara.

Palabras clave: vertido de crudo del Prestige, Mytilus galloprovincialis, Tetraselmis sp., fracción acomodada en agua, biomarcadores. 


\section{INTRODUCTION}

The spill of more than 60000 tonnes of a heavy fuel (M-100) by the Prestige tanker in November 2002, in front of the Galician coast (NW Spain), produced one of the largest ecological disasters in the region, affecting from Galicia in Spain to Brittany in France. The oil contained a significant amount (ca. 50\%) of polycyclic aromatic hydrocarbons (PAHs) some of them known to be carcinogenic and/or mutagenic to aquatic organisms (Albers, 2003). Shortly after the accident, several monitoring programs were initiated in order to assess the fate of the oil in the marine environment and its accumulation and effects on marine biota (see Mar. Pollut. Bull. Vol. 53).

Mussels are filter-feeding bivalves that are used widely in environmental monitoring due to their ability to bioconcentrate pollutants as well as to respond to their presence (Livingstone, 1987). Moreover, they are of high economic interest to the Galician region with an annual production of more than $26 \times 10^{4}$ tonnes. Mussels, despite their low metabolism compared to fish, respond to oil compounds by means of changes in the mixed-function oxygenase (MFO) system involved in the xenobiotics metabolism, as well as in changes in conjugating enzymes and in the antioxidant response (Livingstone, 2001).

Chemical analysis of the contaminants of concern coupled with a set of sublethal exposure and/or effect biomarkers has been recommended in coastal pollution monitoring. This approach has already been applied in the region (Solé et al., 1996; Porte et al., 2000; 2001a; Moreira et al., 2004) and recently in relation to the Prestige tanker wreck (PérezCadahía et al., 2004; Marigómez et al., 2006; Martinez-Gómez et al., 2006). In line with these studies, the present work integrates the characterisation of the water soluble PAHs derived from the Prestige fuel oil with measuring several MFO components (flavin reductases i.e. $\mathrm{NAD}(\mathrm{P}) \mathrm{H}$ cytochrome $\mathrm{c}$ and NADH ferricyanide reductases) as putative markers of PAH exposure in mussels (Livingstone, 1987; Solé and Livingstone, 2005). The conjugation phase II glutathione $S$-transferase (GST) was also considered since many xenobiotics undergoing phase I (MFO) reactions may be further eliminated in this way (Fitzpatrik et al., 1997). The antioxidant enzyme activities catalase (CAT), total glutathione peroxidase (t-GPX) (sum of selenium dependent and independent forms) and glutathione reductase (GR) were also included. CAT detoxifies $\mathrm{H}_{2} \mathrm{O}_{2}$ to $\mathrm{H}_{2} \mathrm{O}$ and $\mathrm{O}_{2}$, t-GPX and some GST forms detoxify $\mathrm{H}_{2} \mathrm{O}_{2}$ and organic peroxides, and GR maintains the GSSH-GSH balance towards the reduced form. Moreover, the enzymatic biomarker of neurotoxicity, acetylcholinesterase (AChE), was also considered as it is affected not only by pesticides such as carbamates and organophosphates but also by heavy metals, surfactants and complex xenobiotic mixtures including PAHs (Akcha et al., 2000). AChE was determined in gills as it may be considered the first target of water-borne pollutants (Cheung et al., 2004). In addition, the concentration of a main lipid peroxidation (LP) product, the free malondialdehyde, was measured in this organ as an indicator of oxidative damage.

Despite the existence of several studies that evaluate the impact of oil spillages in the field using mussels as sentinels, few have focused on the shortterm effects of complex mixtures of water soluble PAHs from the oils under laboratory exposure. Furthermore, most of those controlled experiments are focused on particular highly toxic/carcinogenic oil components, such as benzo[a]pyrene $(\mathrm{BaP})$ (Canova et al., 1998; Okay et al., 2000; Akcha et al., 2000; Cheung et al., 2004). This may be adequate for certain types of oils enriched in high molecular weight PAHs; however, this is not the case of the Prestige spill in which the alkylated 2-3 aromatic ring PAHs predominate (Albaigés and Bayona, 2003). These components have been reported to have, at sublethal environmentally realistic concentrations, a narcotic effect on invertebrates (Barata et al., 2005), exhorting certain genotoxicity in $M$. edulis (Hamountene et al., 2002) but a negligible toxic effect on fish (Seruto et al., 2005). Moreover, no cytotoxic effects were observed in RTG-2 cells, no effects on the growth of Chlorella vulgaris nor acute or reproductive effects on Daphnia magna exposed to the water accommodated fraction (WAF) of the Prestige oil (Navas et al., 2006).

The aim of this study was to evaluate, in mussels, the short-term response of several biomarkers of PAH exposure to the Prestige oil, by simulating the field concentrations as closely as possible. The oil water-accommodated fraction was obtained following a standardised methodology (Singer et al., 2000), and both dissolved and particulated fuel oil components were administered to mussels through diet and test media using $24 \mathrm{~h}$ pre-exposed algae. 
This environmentally realistic approach also allowed us to enhance the bioavailable PAHs present in the low water soluble Prestige oil.

\section{MATERIAL AND METHODS}

\section{Reagents}

Perdeuterated standards used as surrogates were obtained from Cambridge Isotope Laboratories (Andover, USA). A cyclohexane solution containing the 16 EPA priority PAHs at $10 \mathrm{mg} / \mathrm{L}$ each was obtained from Dr. Ehrenstorfer (Augsburg, Germany). Decafluorobiphenyl was from Merck (Hohenbrunn, Germany). Suprasolv grade methanol, hexane and dichloromethane GR for analysis was obtained from Merck (Darmstadt, Germany). Silica gel and neutral alumina were also obtained from Merck (Darmstadt, Germany), extracted with dichloromethane before use and then activated at $120^{\circ} \mathrm{C}$ overnight. Cytochrome c, NADH (reduced $\beta$-nicotinamide adenine dinucleotide), $\mathrm{NADPH}$ (reduced $\beta$-nicotinamide adenine dinucleotide phosphate), and the other reagents were also obtained from the Sigma Chemical Company.

\section{Water-accommodated fraction (WAF)}

Fuel oil from the Prestige cargo provided by Repsol (A Coruña, Spain) was dissolved in filtered sea-water of 35\%o salinity at a 1:500 (w:v) ratio. The water-accommodated fraction (WAF) of the fuel oil was obtained according to the standardised procedure proposed by Singer et al. (2000). That is, $1 \mathrm{~g}$ of crude was dissolved in $0.5 \mathrm{~L}$ of sea water at room temperature $\left(22-23^{\circ} \mathrm{C}\right)$ and magnetically stirred for 24 hours in a sealed bottle protected from the light, in order to minimise evaporation and degradation of the oil components.

\section{Experimental design}

Two hundred mussels (Mytilus galloprovincialis) with a shell length of $6.9 \pm 0.6 \mathrm{~cm}$ were collected from a pristine area (Roses, NW Mediterranean), held in hanging nets at the laboratory and acclimated for two weeks to the experimental conditions. They were maintained in two round $50 \mathrm{~L}$ tanks (100 mussels in each) containing filtered sea water (temperature $18^{\circ} \mathrm{C} \pm 2$, salinity $37 \mathrm{psu} \pm 0.4$ and $\mathrm{pO}_{2}$
$100 \% \pm 0.3$ ) with a photoperiod regime of $12 \mathrm{~h}$ light-darkness.

During the acclimation period animals were fed daily with $4 \mathrm{~L}$ of the algae Tetraselmis sp. at a density of 1.3-2.5 $\times 10^{5}$. During the experiment, mussels from the exposed tank were fed with algae previously held for 15 hours in a static system of $4 \mathrm{~L}$ seawater flasks and at a low $\mathrm{O}_{2}$ pressure rate with a 1:10,000 crude dilution, obtained from the previously 1:500 filtered WAF (as described above). The entire $4 \mathrm{~L}$ of seawater containing the algae was used to feed the mussels. Mussels from the control tank were fed with $4 \mathrm{~L}$ of unexposed algae. The mussels were kept in flow-through water, which was only stopped during the $4 \mathrm{~h}$ feeding period. Time and doses used were chosen based on the work of Okay et al. (2000) and Pérez-Cadahía et al. (2004).

About 20 specimens were sampled from control and exposed tanks after 2, 4, 7 and 10 days of the crude-feeding experimental initiation period. After sampling, mussels were measured and immediately dissected. Gills and digestive glands were separately frozen in liquid $\mathrm{N}_{2}$ and stored at $-80^{\circ} \mathrm{C}$ until biochemical analysis. The rest of the tissue was homogenised and frozen at $-20^{\circ} \mathrm{C}$ for chemical analysis of PAHs. An aliquot of the original sample was placed at $105^{\circ} \mathrm{C}$ overnight to determine its moisture content.

\section{Chemical analysis of PAHs in the WAF and mussel tissue}

WAF

About $800 \mathrm{~mL}$ of WAF was spiked with the following perdeuterated surrogates, naphthalene (272 $\mathrm{ng}$ ), anthracene (242 ng), pyrene (144 ng) and benzo[ $a]$ pyrene $(244 \mathrm{ng})$ in methanol, and then extracted 4 times with $20 \mathrm{~mL}$ of dichloromethane. The extracts were percolated through anhydrous sodium sulphate (2 g), cautiously evaporated to around $1 \mathrm{~mL}$ and fractionated by column chromatography with neutral alumina and silica gel, both with $6 \mathrm{~g}$, and 5\% deactivated with MilliQ water. Two fractions were obtained, the first containing the aliphatic hydrocarbons and the second PAHs, eluted with $20 \mathrm{~mL}$ of hexane and $50 \mathrm{~mL}$ of hexane : dichloromethane (80:20) respectively.

The collected extracts were rotary evaporated and analysed by gas chromatography coupled to mass spectrometry (GC-MS) using a Trace Thermo- 
Electron Corporation (Austin, TX, USA) in the electron impact (EI) mode at $70 \mathrm{ev}$. Injection was performed in the splitless mode at $280^{\circ} \mathrm{C}$ using hexane as the solvent. The purge valve was activated $50 \mathrm{sec}$ after the injection. A $30 \mathrm{~m} \times 0.25 \mathrm{~mm}$ ID capillary column coated with $0.25 \mu \mathrm{m}$ of ZB-5MS stationary phase was obtained from Phenomenex (Torrance, CA, USA). The column temperature was kept at $60^{\circ} \mathrm{C}$ for $1 \mathrm{~min}$, then the temperature was programmed until $200^{\circ} \mathrm{C}$ at $10^{\circ} \mathrm{C} / \mathrm{min}$ and finally to $320^{\circ} \mathrm{C}$ at $4.8^{\circ} \mathrm{C} / \mathrm{min}$, maintaining the final temperature for $10 \mathrm{~min}$, start acquiring after $6 \mathrm{~min}$. Transfer line and ion source temperatures were kept at 250 and $200^{\circ} \mathrm{C}$ respectively. Acquisition was performed in the full scan mode from 50 to 350 amu at 2 scans/sec (10 scans/peak).

Quantification of the polycyclic aromatic hydrocarbons (PAHs) was performed from the reconstructed ion chromatograms obtained from the molecular ion by the internal standard procedure by using decafluorobiphenyl and recovery correction with the corresponding surrogates.

\section{Mussel tissue}

An aliquot of the sample ( $5 \mathrm{~g}$, wet weight) was placed in a centrifuge tube containing $5 \mathrm{~mL}$ of aqueous $\mathrm{NaOH} 6 \mathrm{M}$ and the sample was spiked with the following perdeuterated surrogates, naphthalene (272 ng), anthracene (242 ng), pyrene (144 ng) and benzo[ $a]$ pyrene $(244 \mathrm{ng}$ ) in methanol. The mixture was left in darkness for $18 \mathrm{~h}$ at $40^{\circ} \mathrm{C}$ and then extracted by sonication 4 times with $10 \mathrm{~mL}$ hexane : dichloromethane $(80: 20)$, separating the phases by centrifugation. The extracts were passed through anhydrous sodium sulphate $(2 \mathrm{~g})$, cautiously evaporated to around $1 \mathrm{~mL}$ and fractionated and analysed for PAHs as indicated above.

\section{Biochemical analyses}

Two digestive glands (ca. 0.5-1 g wet wt.) were used for each of the 4 or more replicates made per assay. Samples were homogenised in $10 \mathrm{mM}$ Tris- $\mathrm{HCl}$ $\mathrm{pH} 7.6$ containing $0.15 \mathrm{M} \mathrm{KCl}$ and $0.5 \mathrm{M}$ sucrose in a tissue:buffer ratio of 1:4 (w/v) using an electricallydriven Polytron ${ }^{\circledR}$ homogeniser. Following centrifugations at $12000 \mathrm{~g} \times 30 \mathrm{~min}$ and $100000 \mathrm{~g} \times 60 \mathrm{~min}$, the supernatant obtained was the cytosol and the pellet was the microsomal fraction. The latter was further resuspended in $10 \mathrm{mM}$ Tris- $\mathrm{HCl} \mathrm{pH} 7.6$ containing $20 \%(\mathrm{w} / \mathrm{v})$ glycerol to give a protein concentration of approximately $10 \mathrm{mg} \mathrm{mL}^{-1}$. The whole procedure was conducted either in ice or at $4^{\circ} \mathrm{C}$.

Pooled gill tissue (0.05-0.1 g wet wt) corresponding to aprox 2-4 individuals was also homogenised with the Polytron ${ }^{\circledR}$ homogeniser in a $100 \mathrm{mM}$ Tris $\mathrm{pH}$ 8.0 buffer and at a tissue:buffer 1:5 (w/v) ratio. Gill measurements were carried out in the supernatant resulting from a $9000 \mathrm{~g} \times 30$ min centrifugation.

All assays were carried out in duplicate at $25^{\circ} \mathrm{C}$, and in a final reaction volume of $1 \mathrm{ml}$ (GPX, GR, reductases, AChE and LP) or $3 \mathrm{ml}$ (catalase). Catalase (CAT) activity was measured by the decrease in $\mathrm{H}_{2} \mathrm{O}_{2}$ at $240 \mathrm{~nm}\left(\varepsilon=40 \mathrm{M}^{-1} \mathrm{~cm}^{-1}\right)$ using quartz cuvettes. Total Glutathione peroxidase (t-GPX) activity was measured by the NADPH consumption at $340 \mathrm{~nm}(\varepsilon$ $=6.2 \mathrm{mM}^{-1} \mathrm{~cm}^{-1}$ ) during the formation of reduced glutathione by commercial glutathione reductase (GR). Glutathion $S$ - transferase (GST) was measured using 1-chloro-2,4-dinitrobenzene (CDNB) as change in $\mathrm{OD} / \mathrm{min}$ at $340 \mathrm{~nm}\left(\varepsilon=9.6 \mathrm{mM}^{-1} \mathrm{~cm}^{-1}\right)$, a more detailed description of the protocols can be found in Solé et al., (1996). Glutathione reductase (GR) was also measured by the NADPH consumption following the Carlberg and Mannervik protocol (1985). Acetylcholinesterase (AChE) was measured using $100 \mu \mathrm{L}$ of the gill supernatant fraction by the Ellman method (1961). Lipid peroxidation (LP) was measured using $200 \mu \mathrm{L}$ of the same gill fraction and absorbance was read at $586 \mathrm{~nm}$ versus a standard solution of 1,1,3,3-tetramethoxypropane as described in Durand et al. (2002).

Microsomal NAD(P)H-dependent cytochrome c and NADH-dependent ferricyanide reductase activities were measured respectively by the increase in absorbance at $550 \mathrm{~nm}$ (ext. coeff. $19.6 \mathrm{mM}^{-1} \mathrm{~cm}^{-1}$ ) and the decrease in absorbance at $420 \mathrm{~nm}$ (ext. coeff. $1.02 \mathrm{mM}^{-1} \mathrm{~cm}^{-1}$ ). Final assay conditions in a final volume of $1 \mathrm{~mL}$ were: $50 \mathrm{mM}$ Tris- $\mathrm{HCl} \mathrm{pH} 7.6,1$ $\mathrm{mM} \mathrm{KCN}, 0.26 \mathrm{mM} \mathrm{NAD}(\mathrm{P}) \mathrm{H}$, and $30 \mu \mathrm{M}$ cytochrome c or $0.2 \mathrm{mM}$ potassium ferricyanide. Sample volumes were: $50 \mu \mathrm{L}$ of microsomes for $\mathrm{NADPH}$ and $10 \mu \mathrm{L}$ for NADH dependent reductases (Solé and Livingstone, 2005).

Total protein was determined by Bradford's method (1976) using bovine serum albumin as standard.

\section{Statistics}

Non-parametric analyses were used for correlations and comparisons between treatments due to the 
TABLE 1. - Concentration of PAHs in the WAF used for the experiment and mean mussel tissue concentration during the experiment (considering control and exposed tanks at all time exposures) and the corresponding bioconcentration factors (BCF).

\begin{tabular}{|c|c|c|c|c|}
\hline PAHs (Nr. of rings) & Acronym & Water 1:500 (mg/L) & $\begin{array}{l}\text { Mussel tissue }{ }^{b} \text { (min-max.) } \\
\text { (ng/g d.w) }\end{array}$ & $\mathrm{BCF}^{\mathrm{a}}$ \\
\hline Naphthalene (2) & $\mathrm{N}$ & 45.7 & $13.3 \pm 1.7(7.7-21.2)$ & $1.1 \pm 0.1$ \\
\hline Methylnaphthalenes (2) & N1 & 55.3 & $21.3 \pm 2.5(13.9-32.8$ & $1.5 \pm 0.2$ \\
\hline Dimethylnaphthalenes (2) & $\mathrm{N} 2$ & 52.7 & $65.4 \pm 4.3(46.2-85.7$ & $4.9 \pm 0.4$ \\
\hline Trimethylnaphthalenes (2) & $\mathrm{N} 3$ & 19.6 & $66.9 \pm 7.3(40.8-94.7)$ & $13.5 \pm 1.4$ \\
\hline Fluorene (2) & $\mathrm{F}$ & 2.50 & $12.0 \pm 1.0(6.4-14.1)$ & $18.9 \pm 1.7$ \\
\hline Phenanthrene (3) & $\mathrm{Ph}$ & 3.33 & $15.9 \pm 0.6(13.4-18.2)$ & $19.5 \pm 0.8$ \\
\hline Methylphenanthrenes (3) & Ph1 & 3.28 & $23.1 \pm 2.0(16.6-32.4)$ & $3.0 \pm 0.2$ \\
\hline Dimethylphenanthrenes (3) & $\mathrm{Ph} 2$ & 2.71 & $29.5 \pm 3.1(18.0-46.1)$ & $2.7 \pm 0.3$ \\
\hline Trimethylphenanthrenes (3) & $\mathrm{Ph} 3$ & n.d. & $22.2 \pm 1.3(18.4-29.1)$ & n.c. \\
\hline Anthracene (3) & A & 0.40 & $5.5 \pm 0.4(4.0-7.8)$ & $4.0 \pm 0.4$ \\
\hline Dibenzothiophene (3) & $\mathrm{D}$ & 3.04 & $8.2 \pm 0.7(5.6-11.9)$ & $3.9 \pm 0.4$ \\
\hline Methyldibenzothiophenes (3) & D1 & 1.78 & $10.6 \pm 0.7(7.1-12.5)$ & $24.4 \pm 1.8$ \\
\hline Dimethyldibenzothiophenes (3) & D2 & 1.08 & $19.4 \pm 1.4(13.1-25.2)$ & $74.3 \pm 5.4$ \\
\hline Trimethyldibenzothiophenes (3) & D3 & n.d. & $19.7 \pm 1.3(16.8-23.8)$ & n.c. \\
\hline Fluoranthene (4) & $\mathrm{Fl}$ & 0.13 & $8.7 \pm 0.4(7.0-10.3)$ & $276 \pm 12.5$ \\
\hline Pyrene (4) & Py & 0.28 & $12.8 \pm 1.6(9.9-23.8)$ & $204 \pm 25.5$ \\
\hline Methylpyrenes (4) & Py1 & 0.49 & $7.2 \pm 0.4(5.4-8.7)$ & $60.3 \pm 3.5$ \\
\hline Benzo[a]anthracene (4) & $\mathrm{BaA}$ & 0.15 & $8.6 \pm 0.4(6.8-10.5)$ & $231 \pm 15.0$ \\
\hline Chrysene (4) & $\mathrm{C}$ & 0.25 & $7.2 \pm 0.3(5.4-8.3)$ & $118 \pm 5.9$ \\
\hline Benzo $[b]$ fluoranthene (5) & $\mathrm{BbF}$ & 0.08 & $10.9 \pm 0.4(9.7-13.4)$ & $556 \pm 32.2$ \\
\hline Benzo $[k]$ fluoranthene $(5)$ & $\mathrm{BkF}$ & 0.02 & $7.2 \pm 0.6(5.8-10.1)$ & $1578 \pm 138.2$ \\
\hline Benzo $[e]$ pyrene $(5)$ & $\mathrm{BeP}$ & 0.32 & $10.4 \pm 0.7(8.6-13.3)$ & $131 \pm 10.7$ \\
\hline Benzo $[a]$ pyrene $(5)$ & $\mathrm{BaP}$ & 0.14 & n.d. & n.d. \\
\hline Perylene (5) & Per & 0.05 & $6.4 \pm 0.5(5.0-8.3)$ & $436 \pm 73.6$ \\
\hline Indeno[1,2,3-cd]pyrene (6) & IPy & 0.04 & n.d. & n.d. \\
\hline Benzo[ghi]perylene (6) & BPer & 0.06 & n.d. & n.d. \\
\hline DiBenzo $[a h]$ anthracene (5) & DBA & 0.05 & n.d. & n.d. \\
\hline
\end{tabular}

${ }^{a} \mathrm{BCF}$ is calculated as: concentration in mussel tissue without digestive gland (ng/g wet weight) / concentration in water (mg/L). Data expressed as mean $\pm \mathrm{SD}(\mathrm{n}=8)$ considering all times and exposures; ${ }^{\mathrm{b}}$ Data expressed as mean $\pm \mathrm{SD}(\mathrm{n}=8)$; $\mathrm{n} . \mathrm{d} .=\mathrm{not}$ detected; $\mathrm{n} . \mathrm{c} .=\mathrm{not}$ calculated

small number of replicates, which could not ensure normality or homogeneity of variances. KruskalWallis two-way ANOVA was used to determine whether there were significant differences in chemical and bio-chemical markers, using exposure/control and time as factors. The significance of the Kruskal-Wallis statistic was assessed using the chi-square test (Sokal and Rohlf, 1981). The correlation between chemical and biochemical markers was assessed with Spearman's correlation coefficient $(\rho$, Sokal and Rohlf, 1981). The significance of the $\rho$ statistic was assessed with a $t$-test. In both the Kruskal-Wallis twoway ANOVA and the correlation analyses the significance level was set at $\alpha=0.05$.

\section{RESULTS AND DISCUSSION}

\section{PAH bioaccumulation}

The chemical composition of the WAF fraction (1:500) used for the experiment exposure as well as the concentration of individual PAHs and their alkyl derivatives in mussel tissue are shown in Table 1. The contribution of the different types of PAHs throughout the experiment, according to the number of aromatic rings, is summarised in Figure 1. The presence of PAHs in control mussels may be due to their presence in the sea water used for the experiment. A previous collection of mussels from the vicinity of the water supply already showed similar PAH levels (Baumard et al., 1998). However, exposed organisms showed significantly higher contents of alkylated 2-3 ring PAHs, namely N3 $(\rho=0.873, p=0.005), P h 1 \quad(\rho=0.873, p=0.005), P h 2$ $(\rho=0.764, p=0.027)$ and $\operatorname{Ph} 3(\rho=0.873, p=0.005)$, which are some of the most representative components of Prestige fuel oil. However, no significant

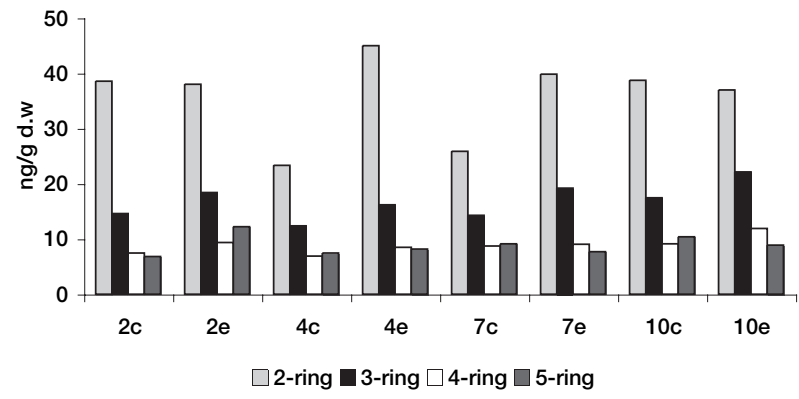

FIG. 1. - Concentration of PAHs (in relation to the number of rings) in water (upper-right graph) and in mussel tissue (lower graph); c, control; e, exposed. 2, 4, 7 and 10 days since the initiation of the 
TABLE 2. - Protein yield (PY), antioxidant enzymes (CAT, t-GPX and GR) and phase II (GST) activity analysed in the cytosolic fraction of the digestive gland of Mytilus galloprovincialis.

\begin{tabular}{llccccc}
\hline Days & & PY & CAT & t-GPX & GR $^{3}$ & GST $^{3}$ \\
\hline 2 & Control (n=4) & $154 \pm 22.2$ & $6.7 \pm 1.0$ & $8.9 \pm 1.4$ & $4.3 \pm 0.8$ & $13.0 \pm 2.2$ \\
& Exposed (n=4) & $143.2 \pm 11.0$ & $4.5 \pm 0.1$ & $12.1 \pm 1.0$ & $4.5 \pm 0.3$ & $11.6 \pm 1.0$ \\
4 & Control (n=4) & $98.0 \pm 12.3$ & $4.9 \pm 0.9$ & $15.1 \pm 2.3$ & $5.5 \pm 0.8$ & $14.4 \pm 0.7$ \\
7 & Exposed (n=4) & $126.5 \pm 11.9$ & $6.6 \pm 2.4$ & $9.9 \pm 1.7$ & $4.4 \pm 0.3$ & $17.7 \pm 0.9$ \\
& Control (n=4) & $119.7 \pm 20.2$ & $6.7 \pm 0.9$ & $19.5 \pm 2.4$ & $4.9 \pm 0.7$ & $14.7 \pm 2.3$ \\
10 & Exposed (n=4) & $113.3 \pm 18.0$ & $8.5 \pm 1.0$ & $17.4 \pm 3.7$ & $5.1 \pm 0.8$ & $12.5 \pm 3.1$ \\
& Control (n=4) & $115.4 \pm 13.0$ & $6.6 \pm 0.4$ & $19.7 \pm 1.4$ & $7.1 \pm 0.4$ & $11.4 \pm 1.9$ \\
& Exposed (n=4) & $102.3 \pm 2.4$ & $12.6 \pm 1.1$ & $23.4 \pm 4.1$ & $6.9 \pm 0.6$ & $13.8 \pm 0.8$ \\
\hline
\end{tabular}

${ }^{1} \mathrm{mg}$ protein $\mathrm{g}^{-1}$ wet weight ${ }^{2} \mathrm{mmol} \mathrm{min}^{-1} \mathrm{mg} \mathrm{prot}^{-1} ;{ }^{3} \mathrm{nmol} \mathrm{min}^{-1} \mathrm{mg}_{\text {prot }}{ }^{-1}$

increase over time was seen for any of the individual PAHs analysed, which probably indicates a steady state situation. Thus, the PAH bioconcentration factors $(\mathrm{BCF})$ were calculated considering the concentrations in the water and in the mussel tissue (without the digestive gland) for all eight situations (Table 1). In general, the BCF values increased with the PAH ring number, except for the high molecular weight components which were not well represented in the oil WAF. In this respect, it has been reported that exposure of mussels to higher doses of $\mathrm{BaP}$ (2 and $50 \mu \mathrm{g} / \mathrm{L}$ ) do not reach a steady state situation even after 15 days of exposure (Okay et al., 2000).

The reason for the lack of significant bioaccumulation in the present study could be due to: (1) the composition of the WAF, which is enriched in low molecular weight compounds that can be rapidly released to the atmosphere and therefore are not available for aquatic organisms, (2) the further 1:10000 dilution of the 1:500 extract that, although it simulates the maximal solubility of the oil, may be too low to cause any significant bioaccumulation over our experimental temporal span, and (3) the 4 hour feeding period, although theoretically sufficient for the mussels to filter the entire $50 \mathrm{~L}$ of water, may not have been sufficient for the exposed mussels to do so. Overall, the PAH contents in mussels in our laboratory experiment is in line with those reported for background levels of PAHs in mussels in the Mediterranean (Baumard et al., 1998), those regained in the Galician coast 3 years after a major spillage (Porte et al., 2001a) or even in postlarval mussel recruits from the Galician coast recently after the actual Prestige spillage (Labarta et al., 2005).

\section{Biochemical markers}

\section{Digestive gland responses}

A selection of the biochemical responses in mussels, as an indication of the PAH exposure and associated with oxidative stress, was based on evidence from other laboratory and field studies. The measured biochemical responses in the two groups of mussels (control and exposed) and over time in the cytosolic and microsomal fractions of the digestive gland are given in Tables 2 and 3 respectively. Apparently, the cytosolic parameters analysed were not affected by the exposure but the antioxidant responses CAT $\left(\mathrm{KW}_{1,3}=8.48, \mathrm{p}=0.037\right), \mathrm{GR}$ $\left(\mathrm{KW}_{1,3}=11.20, \mathrm{p}=0.011\right)$ and $\mathrm{t}-\mathrm{GPX}\left(\mathrm{KW}_{1,3}=10.85\right.$,

TABLE 3. - Protein yield (PY) and flavin monooxygenase (MFO) components analysed in the microsomal fraction of the digestive gland of Mytilus galloprovincialis.

\begin{tabular}{|c|c|c|c|c|c|}
\hline Days & & $\mathrm{PY}^{1}$ & $\begin{array}{l}\text { NADPH } \\
\text { cyt c red }{ }^{2}\end{array}$ & $\begin{array}{l}\text { NADH } \\
\text { cyt c red }\end{array}$ & $\begin{array}{c}\text { NADH } \\
\text { ferricyanide red }\end{array}$ \\
\hline \multirow[t]{2}{*}{2} & Control $(n=5)$ & $4.7 \pm 0.8$ & $11.5 \pm 1.9$ & $46.7 \pm 2.8$ & $403.6 \pm 52.5$ \\
\hline & Exposed $(n=5)$ & $4.0 \pm 0.9$ & $8.8 \pm 1.5$ & $57.4 \pm 7.3$ & $458.7 \pm 20.7$ \\
\hline \multirow[t]{2}{*}{4} & Control $(n=4)$ & $3.7 \pm 0.4$ & $11.9 \pm 2.6$ & $56.3 \pm 5.4$ & $376.3 \pm 41.8$ \\
\hline & Exposed $(n=4)$ & $3.3 \pm 0.1$ & $10.7 \pm 0.7$ & $60.7 \pm 5.2$ & $403.7 \pm 31.9$ \\
\hline \multirow[t]{2}{*}{7} & Control $(n=4)$ & $4.1 \pm 0.5$ & $13.5 \pm 2.1$ & $54.3 \pm 5.4$ & $363.0 \pm 32.3$ \\
\hline & Exposed $(n=4)$ & $3.4 \pm 0.2$ & $15.4 \pm 1.3$ & $65.7 \pm 1.3$ & $434.2 \pm 29.8$ \\
\hline \multirow[t]{2}{*}{10} & Control $(n=5)$ & $4.2 \pm 0.5$ & $12.0 \pm 1.0$ & $48.9 \pm 3.8$ & $319.0 \pm 27.4$ \\
\hline & Exposed $(n=5)$ & $4.3 \pm 0.4$ & $16.4 \pm 3.4$ & $59.0 \pm 5.3$ & $387.9 \pm 24.5$ \\
\hline
\end{tabular}

${ }^{1} \mathrm{mg}$ protein $\mathrm{g}^{-1}$ wet weight; ${ }^{2} \mathrm{nmol} \mathrm{min}^{-1} \mathrm{mg} \mathrm{prot}^{-1}$ 
$\mathrm{p}=0.013$ ) exhibited a statistically significant increase with time.

A relationship between PAH exposure and the increase in antioxidant defences (e.g. CAT, t-GPX, GR) has been put forward (Cajaraville et al., 1992; Cheung et al., 2004) but mostly related to high molecular weight PAHs (e.g. BaP). Nevertheless, consistency of results has not always been achieved and depletion or no-effect on these parameters has also been reported (Solé et al., 1996; Porte et al., 2000; 2001b Livingstone, 2001). Similar observations apply to the cytosolic GST activity. This phase II enzyme was enhanced in gill and digestive gland (Fitzpatrick et al., 1997); digestive gland (Gowland et al., 2002) and gill (Cheung et al., 2004) in relation to multi-ring PAH exposure. However, the contrary has also been described in whole mussel tissue (Michel et al., 1993) and gill tissue (Akcha et al., 2000). Apart from tissue differences there are several isoforms of GST enzymes in mussels and using CDNB as common substrate might not be as adequate as using other particular substrates that are more specific and inducible (Fitzpatrick et al., 1997).

Three reductase activities were measured in the microsomal fraction of the digestive gland and as components of the CYP-monooxygenase system (Table 3). Only the NADH dependent cyt c $\left(\mathrm{KW}_{1,3}=4.766, \quad \mathrm{p}=0.029\right)$ and ferricyanide $\left(\mathrm{KW}_{1,3}=4.229, \mathrm{p}=0.0397\right)$ reductases showed a significant effect due to exposure but not over time. Not only monooxygenases are involved in the metabolism of xenobiotics, endogenous molecules such as fatty acids and sterols are also metabolised in this way. This fact could imply a change in the fatty acid profile as already pointed out in Labarta et al., (2005) in relation to the Prestige spillage. The three reductases followed the trend observed in other molluscs including bivalves (Solé and Livingstone, 2005). That is: NADH-ferricyanide $>$ NADHcytochrome c>NADPH-cytochrome c reductase indicative of cytochrome $b 5$ reductase, cytochrome $b 5$ reductase and cytochrome $b 5$ and CYP reductase respectively. Activity levels of NADPH reductase were within the range of those observed in laboratory (Okay et al., 2000) and field studies (Porte et al., 2000). Induction of these reductases in relation to PAHs has been reported in some studies (Michel et al., 1993; D'Adamo et al., 1997), but not in others (Solé et al., 1996; Porte et al., 2001b).

A relative insensitivity of the MFO system (NADPH cyt c reductase form) to the Prestige oil exposure is in line with observations of fish which do not respond to petroleum containing predominantly low molecular weight PAHs (Seruto et al., 2005). This lack of response in our study is supported by the fact that much higher levels of encapsulated $\mathrm{Ph}, \mathrm{Fl}$ and $\mathrm{BaP}$, than those found in our mussels, were required to exert an effect on CAT and NADPH reductase in M. edulis (Krishnakumar et al., 1997) or for water-borne BaP to cause CYP1A induction and oxidative damage in $M$. galloprovincialis (Canova et al., 1998). In fact, dilutions lower than 1:500 of the WAF of the Prestige oil were necessary to induce the MFO dependent EROD activity in exposed RTG-2 cells (Navas et al., 2006).

Protein yield (PY), as a general marker of increased hepatic metabolism due to xenobiotics exposure, was also considered. Although it did not indicate a significant effect of exposure conditions, in the cytosolic fraction these values were markedly higher than those obtained for other field mussels following a similar protocol procedure (personal observation). However, the microsomal fraction displayed similar PY values to mussels from other field surveys. This could explain the fact that most cytosolic determinations for specific activities in our study are lower than those reported elsewhere (Solé et al., 1996; Porte et al., 2001b). Other proteins could be enhanced under our experimental conditions (e.g. stress proteins) and explain the higher cytosolic total protein load.

\section{Gill responses}

Mussels' gills are the organs that first come into contact with waterborne pollutants. Gill AChE activity has been suggested as an adequate biomarker of exposure to neurotoxic compounds in these organisms in relation to an oil spillage (Moreira et al., 2004). In the present study, no difference in gill AChE activity was observed in exposed mussels in relation to the control (Table 4). Moreover, no significant time-dependence of this response was detected $\left(\mathrm{KW}_{1,3}=3.737, \mathrm{p}=0.291\right)$. Indeed, the present PAH concentrations in mussels are similar to those found under "normal" field situations (Baumard et al., 1998), so that a lack of response in the exposed specimens is not surprising. However, the gill AChE values obtained in our study are in the range of those observed in the same species under laboratory conditions (Akcha et al., 2000) but lower than those observed in field mussels (40-46 
380 - M. SOLÉ et al.

TABLE 4. - Protein yield (PY), the neurotoxicity marker (AChE) and the oxidative damage marker (LP) analysed in gills of Mytilus galloprovincialis

\begin{tabular}{|c|c|c|c|c|}
\hline \multicolumn{2}{|c|}{ Days } & \multirow{2}{*}{$\begin{array}{c}\mathrm{PY}^{1} \\
11.4 \pm 1.2\end{array}$} & \multirow{2}{*}{$\frac{\mathrm{AChE}^{2}}{11.8 \pm 2.3}$} & \multirow{2}{*}{$\begin{array}{c}\mathrm{LP}^{3} \\
32.5 \pm 1.3\end{array}$} \\
\hline 2 & Control (n=6) & & & \\
\hline & Exposed $(n=6)$ & $13.4 \pm 0.8$ & $13.1 \pm 1.1$ & $39.4 \pm 3.6$ \\
\hline 4 & Control $(n=6)$ & $9.7 \pm 1.0$ & $13.9 \pm 2.5$ & $30.7 \pm 3.1$ \\
\hline & Exposed $(n=6)$ & $16.0 \pm 1.2$ & $9.2 \pm 0.8$ & $45.9 \pm 2.6$ \\
\hline \multirow{2}{*}{7} & Control $(\mathrm{n}=6)$ & $10.4 \pm 1.0$ & $8.9 \pm 1.4$ & $34.5 \pm 2.1$ \\
\hline & Exposed $(n=6)$ & $11.0 \pm 0.9$ & $12.0 \pm 0.9$ & $37.8 \pm 3.5$ \\
\hline & Control $(n=6)$ & $10.3 \pm 1.2$ & $14.6 \pm 3.7$ & $45.5 \pm 3.5$ \\
\hline & Exposed $(n=6)$ & $10.5 \pm 0.4$ & $13.6 \pm 1.4$ & $43.3 \pm 2.9$ \\
\hline
\end{tabular}

${ }^{1}$ mg protein $\mathrm{g}^{-1}$ wet weight ${ }^{2} \mathrm{nmol} \mathrm{min}^{-1} \mathrm{mg}_{\text {prot }}{ }^{-1} ;{ }^{3} \mathrm{nmol} \mathrm{MDA} \mathrm{g}{ }^{-1}$ wet weight

$\mathrm{nmol} / \mathrm{min} / \mathrm{mg}$ prot) over a two year study (Bodin et $a l ., 2004)$ or in mussels from the Mediterranean (24$31 \mathrm{nmol} / \mathrm{min} / \mathrm{mg}$ prot) exposed to a pollution gradient (Porte et al., 2001b). Two factors could partly explain these differences: (1) the use of a protein membrane solubiliser in Bodin et al. (2004) and/or (2) a worse fitness condition in mussels exposed to laboratory conditions. Long (up to 30 day) acclimation periods have been recommended in mussels (D'Adamo et al., 1997) to avoid the effect of the adaptation factor.

LP, as an indicator of oxidative stress damage was also evaluated in gills. Unlike $\mathrm{AChE}$, the treatment had an effect of this effect marker $\left(\mathrm{KW}_{1,3}=6.328, \mathrm{p}=0.012\right)$. In Table 5 the Spearman rank correlation for only those biomarkers that showed a significant relation to any of the individual PAHs is presented. Correlations between chemical body burden and biochemical responses were mostly significant for LP. In fact, LP was the only marker to significantly correlate with most individual PAHs. This suggests that the treatment had a negative effect on the mussels exposed to environmentally realistically low doses of petrogenic PAHs and that the actual defence system (not being induced under exposure) was not able to cope with any ROS formed. Nevertheless, LPO damage has mostly been associated with BaP exposure (Solé et al., 1996; Porte et al.,. 2000; Cheung et al., 2004; Durand et al., 2002).

TABLE 5. - Summary of Spearman rank correlation $(\rho)$ and significant level $(\alpha)$ for individual PAHs and biochemical responses. Only biomarkers displaying some significant values are considered.

\begin{tabular}{|c|c|c|c|c|c|c|c|c|c|c|}
\hline \multirow[t]{2}{*}{ PAHs } & \multicolumn{2}{|c|}{$\begin{array}{l}\text { NADH cyt c } \\
\text { reductase }\end{array}$} & \multicolumn{2}{|c|}{ CAT } & \multicolumn{2}{|c|}{$\mathrm{t}-\mathrm{GPX}$} & \multicolumn{2}{|c|}{ GR } & \multicolumn{2}{|c|}{ LP } \\
\hline & $\rho$ & $\alpha$ & $\rho$ & $\alpha$ & $\rho$ & $\alpha$ & $\rho$ & $\alpha$ & $\rho$ & $\alpha$ \\
\hline \multicolumn{11}{|l|}{ Naphthalene $0.426 *$} \\
\hline Dimethylnaphthalenes & & & & & & & & & 0.477 & $* *$ \\
\hline Trimethylnaphthalenes & & & & & & & & & 0.364 & $*$ \\
\hline Fluorene & & & & & & & & & 0.369 & * \\
\hline Phenanthrene & & & & & & & 0.370 & * & 0.369 & * \\
\hline Methylphenanthrenes & & & & & & & & & 0.389 & $* *$ \\
\hline Dimethylphenanthrenes & & & 0.614 & $* * *$ & & & & & 0.370 & * \\
\hline Trimethylphenanthrenes & & & 0.539 & $* *$ & & & & & & \\
\hline \multirow{2}{*}{\multicolumn{11}{|c|}{ Anthracene }} \\
\hline \multicolumn{4}{|l|}{ Dibenzotiophene } & & & & & & & \\
\hline Methyldibenzotiophenes & & & & & & & & & 0.3873 & $* *$ \\
\hline Dimethyldibenzotiophenes & & & 0.424 & $*$ & 0.418 & $*$ & 0.438 & * & 0.4043 & $* *$ \\
\hline Trimethyldibenzotiophene & & & & & 0.379 & $*$ & & & 0.4281 & $* *$ \\
\hline Fluoranthene & & & 0.421 & $*$ & 0.416 & $*$ & 0.385 & * & 0.5027 & $* * *$ \\
\hline Pyrene & & & 0.626 & $* * *$ & 0.481 & ** & 0.427 & * & 0.2952 & * \\
\hline Methylpyrenes & & & & & & & & & 0.3980 & ** \\
\hline Benzo[a]anthracene & & & & & & & & & 0.3403 & $*$ \\
\hline Crisene & & & 0.377 & * & & & & & 0.3161 & * \\
\hline Benzo $[b]$ fluoranthene & & & & & & & & & 0.3575 & * \\
\hline \multicolumn{11}{|l|}{ Benzo $[k]$ fluoranthene } \\
\hline Benzo[e]pyrene & & & & & & & & & 0.348 & * \\
\hline Benzo $[a]$ pyrene & n.c. & n.c. & n.c. & n.c. & n.c. & n.c. & n.c. & n.c. & n.c. & n.c. \\
\hline Perylene & & & & & 0.475 & * & & & 0.408 & *** \\
\hline
\end{tabular}

n.c.= not calculated. 


\section{CONCLUSION}

Short-term toxicity in mussels due to environmentally realistic doses of the WAF of the Prestige fuel oil did not seem to be responsible for the induction of most of the digestive gland biomarkers tested. Nevertheless, a certain level of toxicity was observed in gills as increased LP levels were found. NADH reductases were also affected by the exposure, which could affect metabolism of endogenous compounds. Bioaccumulation of the Prestige oil PAHs and its associated effects via ingestion/filtration seem to be less likely ways of endangering the studied mussel species. The characteristics of the Prestige heavy oil, which has low water solubility, underline the fact that the real threat to the coastal marine organisms was mainly produced by oiling during the initial stages of the black tide episode.

\section{ACKNOWLEDGEMENTS}

The present study was funded by the Spanish project VEM2003-20068-CO5-01 from the Spanish Ministry of Education and Science. One of us (A. Buet) received a grant from the MEC (SB20030198).

\section{REFERENCES}

Akcha, F., C., Izuel, P., Venier, H., Budzinski, T. Burgeot and J-F. Narbonne. - 2000. Enzymatic biomarker measurement and study of DNA adduct formation in benzo(a)pyrene-contaminated mussels, Mytilus galloprovincialis. Aquat. Toxicol., 49: 269-287.

Albaigés, J. and J.M. Bayona. - 2003. El Fuel. In: S.R. FernándezLatorre (ed.), La Huella del Fuel. Ensayos Sobre el Prestige, pp. 80-103. Fundación Santiago Rey Fernández-Latorre, A Coruña.

Albers, P.H. - 2003. Petroleum and individual polycyclyc aromatic hydrocarbons. In: D.J. Hoffman, B.A. Rattner, G.A. Burton, J. Cairns (eds), Handbook of Ecotoxicology, pp.1-32. Lewis Publishers, New York.

Barata, C., A. Calbet, E. Saiz, L. Ortiz and J.M. Bayona. - 2005. Predicting single and mixture toxicity of petrogenic polycyclic aromatic hydrocarbons to the copepod Oithona davisae. Environ. Toxicol. Chem., 24: 2992-2999.

Baumard, P., H. Budzinski, P. Garrigues, J.C. Sorbe, T. Burgeot and J. Belloco. - 1998. Concentrations of PAHs (Polycyclic aromatic hydrocarbons) in various marine organisms in relation to those in sediment and to trophic level. Mar. Pollut. Bull., 36: 951-960.

Bodin, N., T. Burgeot, J.Y. Stanisière, G. Bocquené, D. Menard, C. Minier, I. Boutet, A. Amat, Y. Cherel and H. Budzinski. 2004. Seasonal variations of a battery of biomarkers and physiological indices for the mussel Mytilus galloprovincialis transplanted into the northwest Mediterranean Sea. Comp. Biochem. Physiol., 138C: 411-427.

Bradford, M. - 1976. A rapid and sensitive method for the quantification of microgram quantities of protein utilizing the principle of protein dye binding. Anal. Biochem., 72: 248-254.
Cajaraville, M.P., J.A. Uranga and E. Angulo. - 1992. Comparative effects of the water acommodated fraction of three oil son mussels3. Quantitative histochemistry of enzymes related to the detoxication metabolism. Comp. Biochem. Physiol., 103C: 369-377.

Canova, S., P. Degan, L.D. Peters, D.R. Livingstone, R. Voltan and P. Venier. - 1998. Tissue dose, DNA adducts, oxidative DNA damage and CYP1A-immunopositive proteins in mussels exposed to waterborne benzo(a)pyrene. Mutation Res., 399: 17-30.

Carlberg, I. and B. Mannervik. - 1985. Glutathione reductase. Methods Enzymol., 113: 485-490.

Cheung, C.C.C., W.H.L. Siu, B.J. Richardson, S.B. De LucaAbbott and P.K.S. Lam. - 2004. Antioxidant responses to benzo(a)pyrene and Arochlor 1254 exposure in the greenlipped mussel, Perna viridis. Environ. Pollut., 128: 393-403.

D’Adamo, R., S. Pelosi, P. Trotta and G. Sansone. - 1997. Bioaccumulation and biomagnification of polycyclic aromatic hydrocarbons in aquatic organisms. Mar. Chem., 56: 45-49.

Durand, F., L.D. Peters and D.R. Livingstone. - 2002. Effect of intertidal compared to subtidal exposure on the uptake, loss and oxidative toxicity of water-born benzo(a)pyrene in the mantle and whole tissues of the mussel, Mytilus edulis L. Mar. Environ. Res., 54: 271-274.

Ellman, G.L., K.O. Courtney, V. Andrers Jr and R.M. Featherstone. - 1961. A new and rapid colorimetric determination of acetylcholinesterase activity. Biochem. Pharmacol., 7: 88-95.

Fitzpatrick, P.J., J. O'Halloran, D. Sheehan and A.R. Walsh. 1997. Assessment of the glutathione $S$-transferase and related proteins in the gill and digestive gland of Mytilus edulis (L.) as potential organic pollution biomarkers. Biomarkers, 2: 51-56.

Gowland, B., A. McIntosh, I. Davies, C. Moffat and L. Webster. 2002. Implications from a field study regarding the relationship between polycyclic aromatic hydrocarbons and glutathione $S$ transferase activity in mussels. Mar. Environ. Res., 54: 231-235.

Hamountene, D., J.F. Payne, A. Rahimtula and K. Lee. - 2002. The use of the Comet assay to assess DNA damage in hemocytes and digestive gland cells of mussels and clams exposed to water contaminated with petroleum hydrocarbons. Mar. Environ. Res., 54: 471-474.

Krishnakumar, P.K., E. Casillas and U. Varanasi. - 1997. Cytochemical responses in the digestive tissue of Mytilus edulis complex exposed to microencapsulated PAHs or PCBs. Comp. Biochem. Physiol., 118C: 11-18.

Labarta, U., M.J. Fernández-Reiriz, J.L. Garrido, J.M.F. Babarro, J.M. Bayona and Albaigés, J. - 2005. Response of mussel recruits to pollution from the "Prestige" oil spill along the Galicia coast. A biochemical approach. Mar. Ecol. Prog. Ser., 302: $135-145$.

Livingstone, D.R. - 1987. Seasonal responses to diesel oil and subsequent recovery of the cytochrome P-450 monooxygenase system in the common mussel, Mytilus edulis L., and the periwinkle, Littorina littorea L. Sci. Total Environ., 65: 3-20.

Livingstone, D.R. - 2001. Contaminant-stimulated reactive oxygen species production and oxidative damage in aquatic organisms. Mar. Pollut. Bull., 42: 656-666.

Marigómez, I., M. Soto, I. Cancio, A. Orbea, L. Garmendia and M.P. Cajaraville. - 2006. Cell and tissue biomarkers in mussel, and histopathology in hake and anchovy from Bay of Biscay alter the Prestige oil spill (Monitoring campaign 2003). Mar. Pollut. Bull., 53: 287-304.

Michel, X.R., P. Suteau, L.W. Robertson and J.-F. Narbonne. 1993. Effects of benzo(a)pyrene, 3,3',4,4'-tetrachlorobiphenyl and $2,2^{\prime}, 4,4^{\prime}, 5,5^{\prime}$ '-hexachlorobiphenyl on the xenobioticmetabolizing enzymes in the mussel (Mytilus galloprovincialis). Aquat. Toxicol., 27: 3535-344

Moreira, S.M., M. Moreira-Santos, R. Ribeiro and L. Guilhermino. - 2004. The "Coral Bulker" fuel oil spill on the North Coast of Portugal: Spatial and Temporal biomarker responses in Mytilus galloprovincialis. Ecotoxicology, 13: 619-630.

Navas, J.M., M. Babín, S. Casado, C. Fernández and J.V. Tarazona. - 2006. The Prestige oil spill: A laboratory study about the toxicity of the water-soluble fraction of the fuel oil, Mar. Environ. Res., 62: S352-S355.

Okay, O.S., P. Donkin, L.D. Peters and D.R. Livingstone. - 2000. The role of algae (Isochrysis galvana) enrichment on the bioaccumulation of benzo(a)pyrene and its effects on the blue mussel Mytilus edulis. Environ. Pollut., 110: 103-113.

Pérez-Cadahía, B., B. Laffon, E. Pásaro and J. Méndez. - 2004. 
Evaluation of PAH bioaccumulation and DNA damage in mussels (Mytilus galloprovincialis) exposed to spilled Prestige crude oil. Comp. Biochem. Physiol., 138C: 453-460.

Porte, C., X. Biosca, M. Solé and J. Albaigés. - 2000. The Aegean Sea oil spill on the Galician coast (NW Spain). III. The assessment of long-term sublethal effects on mussels. Biomarkers, 5: 436-446.

Porte, C., X. Biosca, M. Solé and J. Albaigés. - 2001a. The integrated use of chemical analysis, cytochrome P450 and stress proteins in mussels to assess pollution along the Galician coast (NW Spain). Environ. Pollut., 112: 261-268.

Porte, C., M. Solé, V. Borghi, M. Martínez, J. Chamorro, A. Torreblanca, M. Ortiz, A. Orbea, M. Soto and M.P. Cajaraville. - 2001b. Chemical, biochemical and cellular responses in the digestive gland of the mussel Mytilus galloprovincialis from the Spanish Mediterranean Coast. Biomarkers, 6: 335-350.

Seruto, C., Y. Sapozhnikova and D. Schlenk. - 2005. Evaluation of the relationship between biochemical endpoints of PAHs exposure and physiological endpoints of reproduction in male California Halibut (Paralichthys californicus) exposed to sediments from a natural oil seep. Mar. Environ. Res., 60: 454-465.
Singer, M.M., D. Aurand, G.E. Bragins, J.R. Clark, G.M. Coelho, M.L. Sowby and R.S. Tjeerdema. - 2000. Standarization of the Preparation and Quantification of water-accommodated fractions of petroleum for toxicity testing. Mar. Pollut. Bull., 40: 1007-1016.

Sokal, R.R. and F.J. Rohlf. - 1981. Biometry. Freeman and Co, San Francisco.

Solé, M. and D.R. Livingstone. - 2005. Components of the cytochrome P450-dependent monooxygenase system and 'NADPH-independent benzo[a]pyrene hydroxylase' activity in a wide range of marine invertebrate species. Comp. Biochem. Physiol., 141C: 20-31.

Solé, M., C. Porte, X. Biosca, C.L. Mitchelmore, J.K. Chipman, D.R. Livingstone and J. Albaigés. - 1996. Effects of the "Aegean Sea" oil spill on biotransformation enzymes, oxidative stress and DNA-adducts in digestive gland of the mussel (Mytilus edulis.L.). Comp. Biochem. Physiol., 113C: 257-265.

Scient. ed.: M. Gaspar.

Received October 25, 2006. Accepted February 19, 2007.

Published online May 24, 2007. 